\title{
Diagnosis of reovirus infection in broiler breeders flocks by using PCR technique in Erbil province
}

\author{
F.A. Isihak \\ Department of Microbiology, College of Veterinary Medicine, University of Mosul, Mosul, Iraq, fanar1976@yahoo.com
}

(Received January 31, 2019; Accepted March 25, 2019)

\begin{abstract}
Avian reoviruses can infect birds without any clinical signs of infection, the infection may associate with different manifestations including viral arthritis/tenosynovitis and malabsorption syndrome. The objective of this study was to use advance methods representing by molecular methods (RT-PCR, RT-qPCR) in the diagnosis of ARV infection in broiler breeders' flocks. A 4 flocks of broiler breeders (ROSS breed) 39 weeks age with approximately $10 \%$ morbidity rate due to Avian Reovirus (ARV). The clinical examination of 16 infected birds revealed unilateral lameness and swelling of hock joint. Blood samples were collected from wing vein of infected birds. Sera were tested for antibodies titer against ARV and Mycoplasma synoviae (MS). 5 of 16 positive samples were selected randomly for amplification by RT-PCR and RT-qPCR. The results showed in postmortem examination of infected birds, unilateral arthritis with visible joint lesions. Antibodies titer measured by ELISA in the sera of birds after 4 and 20 weeks of infection with ARV was positive and high. In RT- PCR 1 of 5 samples gave positive reaction for amplification while in RT-qPCR all five samples gave positive results for amplification in comparison with +ve and -ve control.
\end{abstract}

Keywords: Reovirus, Broiler breeders, RT-PCR, RT-qPCR

Available online at http://www.vetmedmosul.com, (C) 2020, College of Veterinary Medicine, University of Mosul.

This is an open access article under the CC BY 4.0 license (http://creativecommons.org/licenses/by/4.0/).

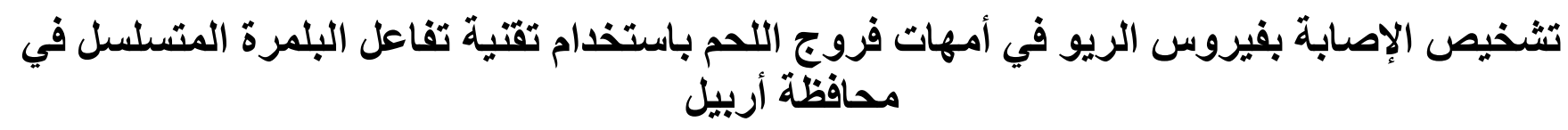

$$
\text { فرع الأحياء المجهرية، كلية الطب البيطري، جامعة الموصل، الموصل، العراق اق البحق }
$$

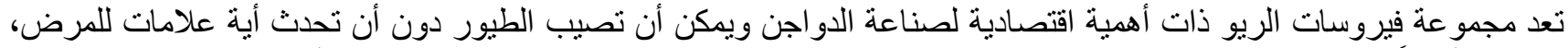

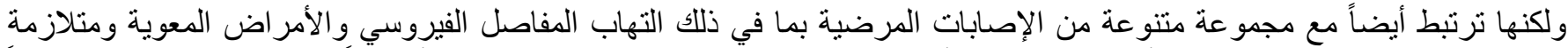

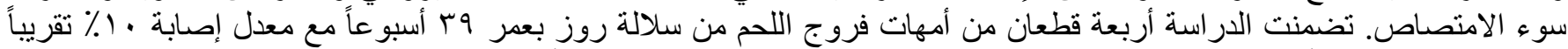

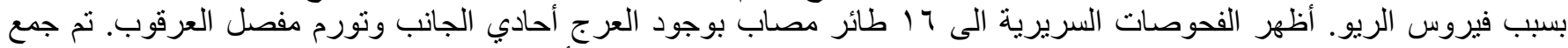

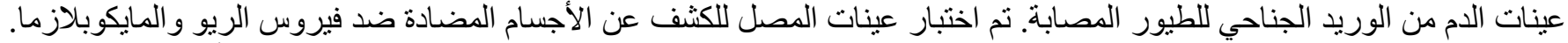

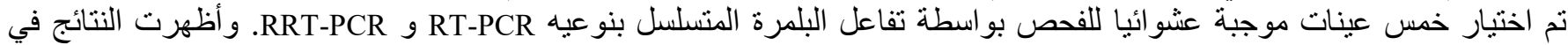

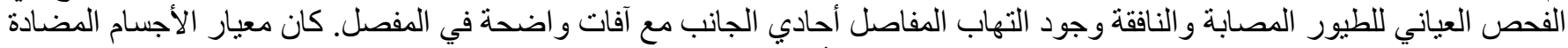

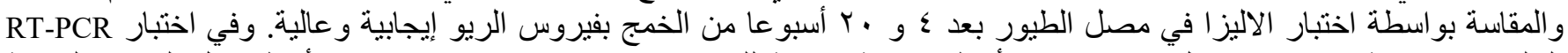

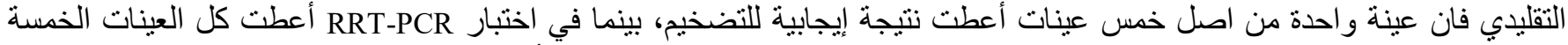

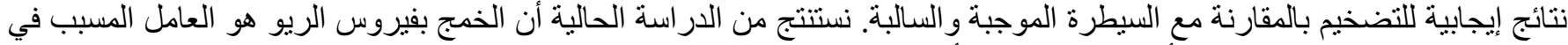

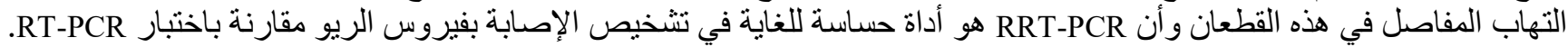




\section{Introduction}

Avian Reoviruses (ARV) are classified as a member of the Orthoreovirus genus, in the family of Reoviridae (1). Reoviruses have been isolated from a different tissue of chickens affected by various disease conditions, including viral arthritis/tenosynovitis, stunting growth syndrome, respiratory and enteric disease, immunosuppressive condition, and malabsorption (2). The virus genome (dsRNA) composed of 10 segments, including 4 small, 3 medium, and 3 large size, classes based on the electrophoretic mobility of these segments. (3) have done full genome sequencing and challenge experiments using selected isolates to confirm the sigma $\mathrm{C}$ typing and look for other genes variability in order to associate them with antigenicity and pathogenicity. Research findings have revealed that the $\sigma \mathrm{C}$ protein encoded by the segment of $\mathrm{S} 1$ genome which represent the cell surface attachment protein and one of the major antigenic determinants for ARVs. The S1 genome segment of existing chicken ARV strains are well characterized and conserved in viruses from chickens (4). In chickens, tenosynovitis/viral arthritis is the most recognized form of ARV associated diseases, and also a significant cause of lameness. Tenosynovitis/arthritis, is predominantly a problem in broiler chickens, and is characterized by lameness and swelling of the hock joint (2). The most critical control approach that limiting the clinical disease associated with ARV infections is vaccination of breeders appropriately with efficacious vaccines, thereby reducing the potential for vertical transmission and providing progeny with specific maternal antibodies that protect against the current field strains. A number of laboratory techniques have been developed for detection antibodies against ARV infection. These include immunofluorescence, serum neutralization, immunediffusion, and enzyme-linked immune-sorbent assay (ELISA) (5). Another useful laboratory diagnostic tool for ARV detection is polymerase chain reaction (PCR) that targeting the $\sigma \mathrm{C}$ gene that encodes the $\sigma \mathrm{C}$ which is consider as the most variable protein in ARV, and it mediates virus attachment to target cells, and antibodies specific for $\sigma \mathrm{C}$ neutralize ARV infections (6). At present, there is insufficient information on the detection of infection with ARV in poultry industry of Iraq, therefore the objective of this study was to use advance methods representing by molecular techniques (RT-PCR, RT-qPCR) in the detection and diagnosis of ARV infection in broiler breeders' flocks.

\section{Materials and methods}

\section{Flocks history}

The study includes 4 flocks of 18000 broiler breeders (ROSS Breed) (39 weeks age) approximately (16200 females and 1800 males). The birds were vaccinated at the hatchery against Marek disease virus. The clinical findings included unilateral lameness and swelling of hock joint and the morbidity of infection with suspected ARV was $10 \%$. The postmortem changes of 16 tested birds showed visible joint lesions.

\section{Blood samples}

A total of thirty-two blood samples were collected after 4- and 20-weeks post infection (16 samples in each collection) from wing vein of infected birds to obtain the serum. Sera were tested for antibodies titer against ARV and Mycoplasma synoviae (MS) to exclude the infection or mixed infection by these bacteria using commercial ELISA Kit for ARV and MS (SYNBIOTICS/ ProFLOK/ Zoetis/ USA) according to the recommended procedure by the manufacturer.

\section{RNA isolation}

SV Total RNA Isolation kit was used according to the manufacturer instructions (Promega Corporation, USA). Viral RNA purification kit supplied for the isolation and yielding of high-quality and tiny amounts of contamination free viral RNA from tissue (joints) for downstream use in RT-PCR and RTq-PCR assay.

\section{Conventional RT-PCR}

A total of five samples out of total sixteen samples were randomly selected for amplification using forward primer (5'-GATGAATACATCCTCAGCGTGC- 3') and reverse primer (5'-ATGAATAGGCGAGTCCCGCTA-3').

These primers were determined to encode $\mathrm{S} 1$ segment of the $\sigma \mathrm{C}$ gene which is one of the four small genes of Reovirus as previously described (7). The PCR reaction was set using one Step Real-Time PCR Enzyme Mix (QIAGEN/ USA). The RT-PCR assay used applied Biosystems universal PCR with master mix $10 \mu 1,6 \mu 1$ of forward primer, $6 \mu \mathrm{l}$ reverse primer, $2 \mu \mathrm{g}$ of cDNA produced from reverse transcribed clinical samples. The PCR reactions were amplified using Veriti Applied Biosystem step one Real-Time PCR system (Germany). The temperature profile consists of initial activation step by incubation at $95^{\circ} \mathrm{C}$ for $15 \mathrm{~min}$ for reverse transcription then followed by 30 cycles for $1 \mathrm{~min}$ at $95^{\circ} \mathrm{C}$ for denaturation step, $1 \mathrm{~min}$ at $60^{\circ} \mathrm{C}$ for annealing process, $1 \mathrm{~min}$ at $72{ }^{\circ} \mathrm{C}$ for elongation of nucleic acid and a final extension step 10 minute at $72{ }^{\circ} \mathrm{C}$.

\section{Agarose gel Electrophoresis}

$12 \mu \mathrm{l}$ of PCR product and DNA ladder of 100-3000 bp size marker were loaded using $1.5 \%$ agarose gel in TAE buffer containing $2 \mu \mathrm{l}$ of ethidium bromide. The electrophoresis continued for $40 \mathrm{~min}$. After that, the gel was visualized using ultraviolet trans-illuminator (8). 


\section{RT-qPCR}

The same 5 of 16 samples was used in this test. briefly the reactions of this techniques were achieved with the GoTaq ${ }^{\circledR} 1$ - Step RT-qPCR Kit (Promega/USA) by using an Applied Biosystem step one Real-Time PCR system (48 wells) (ABI, USA). The temperature profiles include an initial step $\geq 37{ }^{\circ} \mathrm{C}$ for $15 \mathrm{~min}$ for reverse transcription process, RT-PCR inactivation/Hot-Start activation step of $95^{\circ} \mathrm{C}$ for $10 \mathrm{~min}$ then followed by 40 cycles for $10 \mathrm{~s}$ at 95 ${ }^{\circ} \mathrm{C}$ for denaturation step, 30 second at $60{ }^{\circ} \mathrm{C}$ for annealing step, 30 second at $72{ }^{\circ} \mathrm{C}$ for elongation and a final extension step at $60-95{ }^{\circ} \mathrm{C}$. The qPCR assay used applied Biosystems SYBR ${ }^{\circledR}$ Green universal PCR with master mix $25 \mu \mathrm{l}, 5 \mu \mathrm{l}$ from forward primer, $5 \mu \mathrm{l}$ of reverse primer, $10 \mu \mathrm{l}$ of cDNA produced from reverse transcribed clinical samples, $5 \mu \mathrm{MgCl}_{2}$ and $5 \mu \mathrm{l}$ of CXR reference dye.

\section{Results}

\section{Clinical signs}

The infected birds showed signs of unilateral lameness (Curled toes) (Figure 1) and swelling of hock joint (Figure 2 ). The postmortem findings of infected birds showed extent of visible lesions affecting the hock joint including unilateral arthritis and tenosynovitis associated with necrotic lesions in the tip of the tibia (Figure 3).

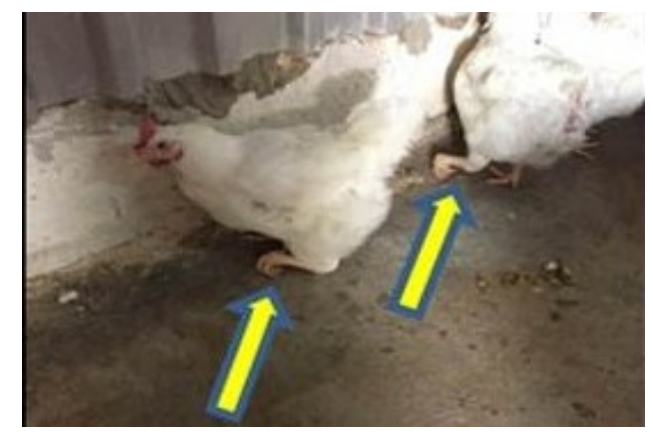

Figure 1: Unilateral lameness (Curled toes).

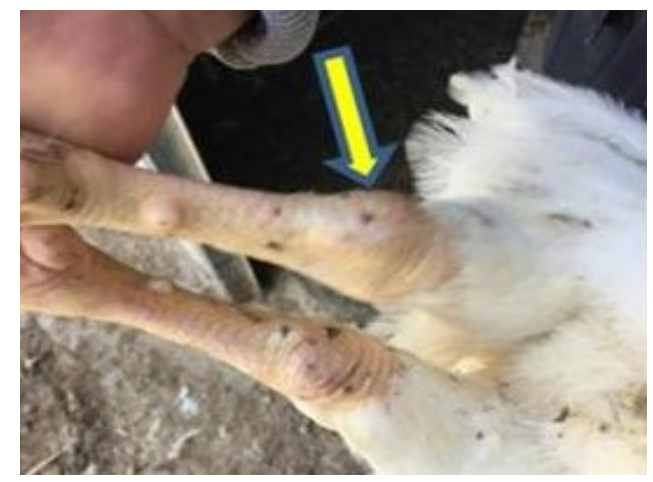

Figure 2: Swelling and edema of hock joint.

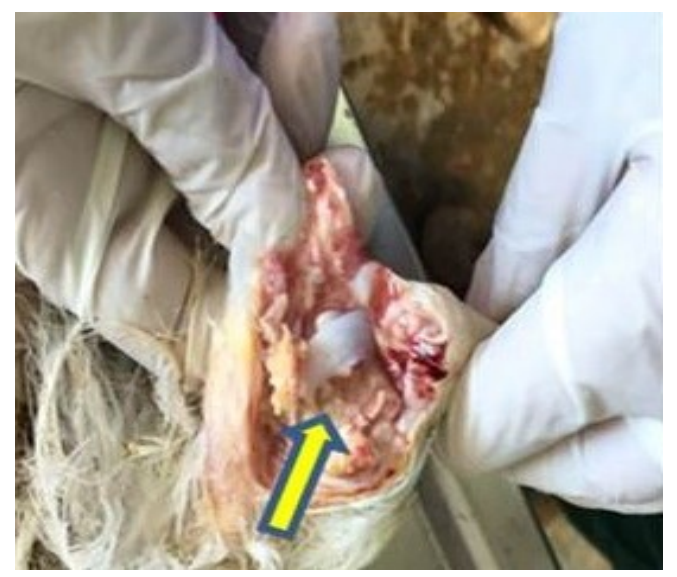

Figure 3: Necrotic lesion associated with arthritis and tenosynovitis affecting the hock joint.

\section{Antibodies titer}

The antibodies titer measured by ELISA in the sera of birds after 4- and 20-weeks post infection with ARV was positive and high (Figure 4), while the antibodies titer was negative (zero) before infection. No antibodies detected in sera of infected birds against Mycoplasma synoviae by ELISA test (Table 1).

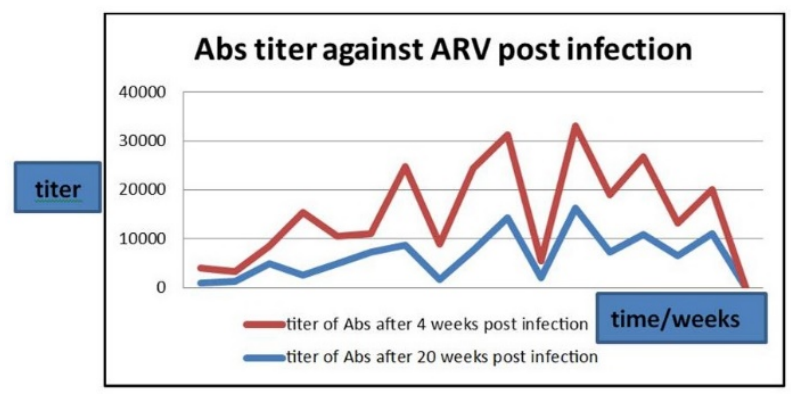

Figure 4: Titer of antibodies after 4 and 20 weeks of infection with ARV obtained by ELISA.

Table 1: Titer of antibodies after 4 and 20 weeks of infection with ARV obtained by ELISA

\begin{tabular}{ccccc}
\hline Number & Minimum & Maximum & Mean & CV\% \\
\hline 16 & 887 & 16329 & 6758 & 65.35 \\
16 & 1976 & 16904 & 9785 & 54.88 \\
\hline
\end{tabular}

\section{Conventional PCR}

The results showed 1 of 5 samples gave positive reaction for amplification (lane 6) while there is no band of precipitation of PCR product by other 4 samples (lane $3,4,5,7$ ) (Figure 5). 


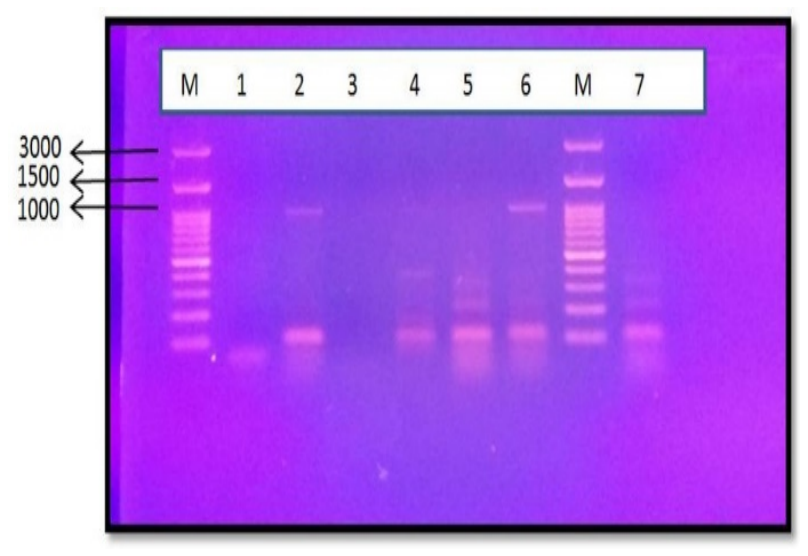

Figure 5: Gel electrophoretic patterns of the PCR product from the $\mathrm{S} 1$ encoding gene of each isolates Lane $\mathrm{M}=$ molecular weight marker $(1 \mathrm{~kb})$, lane $1=-\mathrm{ve}$ control, lane 2 $=+\mathrm{ve}$ control, lane 3-6 and 7=samples.

\section{RT-qPCR}

The specificity of the RT-qPCR assay was verified by examining cDNA product from different samples infected with ARV. All 5 samples gave positive results for amplification in comparison with +ve and -ve control (Figure 6).

\section{Discussion}

Avian Orthoreoviruses are ubiquitous among poultry flocks and have been reported globally. Broiler breeders' flocks stay for long time in the rearing and production periods. This meaning increases the susceptibility to several microbial agents that interfere with the response of immune system and predispose to disease (9). The presence of virus in the infected samples can be confirmed by RT-qPCR.

The Reovirus infection that associated with unilateral lameness and viral arthritis/ tenosynovitis lead to increased mortality, lack of performance, diminished weight gain, different growth rate, reduction in the marketability of the affected birds with viral, and secondary infections from other viruses or bacteria (4).The detectable antibodies in sera of infected birds of non- vaccinated flocks is an evidence for the infection with ARV (11) and the absence of antibodies against $M$. synoviae in sera of infected birds a is an important indicator for the ARV infection and for excluding the infection with $M$. synoviae as the main causative agent or mixed infections with ARV. The mean antibodies titer is 6758 at 4 weeks post infection and this titer is elevated after 20 weeks post infection may be due to circling of virus within the flocks.
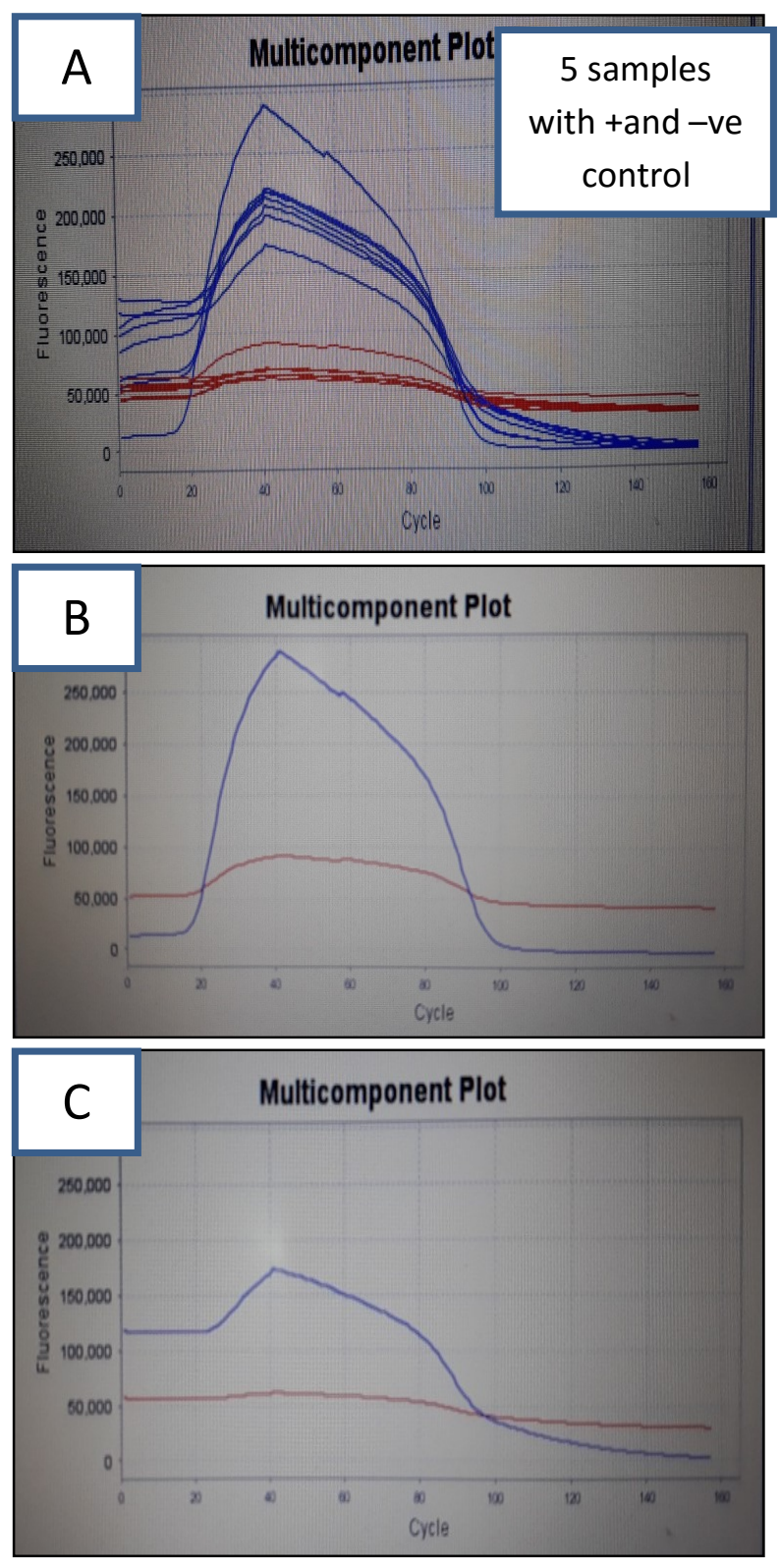

Figure 6: (A) RT-qPCR assay of 5 samples infected with ARV (B) RT-qPCR assay of +ve control (B) RT-qPCR assay of -ve control

The conventional RT-PCR results including 1 of 5 positive samples may be due to the low concentration of viral nucleic acid (RNA) in the samples or due to high sensitivity of RT- qPCR in comparison with conventional RT-PCR (12), While in RT-qPCR all 5 samples gave positive reaction for amplification of cDNA and considered one of powerful tools in the diagnosis of different types of antigens and This test was sensitive, specific and rapid for the detection of ARV and will be useful and very important 
as a veterinary diagnostic procedure in the lab $(13,14)$.The process of sampling, RNA extraction, and the RT-qPCR assay took about 3-4 hours depending on number of samples processed. This is significantly less time compared to traditional virus identification tests, which can take up to 7 days because of virus propagation in chicken embryos or cell culture. Thus, we concluded that the arthritis in these flocks was caused by ARV infection and the RT-qPCR is highly sensitive tool in the detection and diagnosis of ARV than RT-PCR.

\section{Conclusion}

We concluded from current study that the arthritis in these flocks was caused by ARV infection and the RTqPCR is highly sensitive tool in the diagnosis of ARV than RT-PCR.

\section{Acknowledgements}

This research was supported by Kosar Company for Agriculture and Poultry L.T.D./ Erbil//Iraq. The author wishes to thank Dr. Balkees Z. Shaker for technical assistance.

\section{References}

1. Day JM. The diversity of the Orthoreoviruses: Molecular taxonomy and phylogenetic divides. Infect Genet Evolut. 2009;9:390-400.doi: 10.1016/j.meegid.2009.01.011.

2. Roussan DA, Shaheen IA, Khawaldeh GY, Totanji WS, Al-RifaiR H. Simultaneous detection of astrovirus, rotavirus, reovirus and adenovirus type $\mathrm{I}$ in broiler chicken flocks. Polish $\mathrm{J}$ Vet Sci. 2012;15:337-344. DOI: 10.2478/v10181-012-0052-0

3. Labrin S, Roh H, Zhou H, Corsiglia C, Crossley B, Gallardo R. Attempts towards a better classification of avian reovirus variants. $67^{\text {th }}$
Western Poultry Disease Conference. Salt Lake City: USA; 2018. 7678.

4. Jones RC. Viral Arthritis. In: Saif YM, Fadly AM, Glissen JR, McDougald LR, Nolan LK, Swayne DE, editors. Diseases of poultry. $12^{\text {th }}$ ed. New Jersey: Wiley-Blackwell; 2008. 309-328 p.

5. Xie Z, Qin C, Xie L, Liu J, Pang Y, Deng X, Xie Z, Khan M. Recombinant protein-based ELISA for detection and differentiation of antibodies against avian reovirus in vaccinated and non-vaccinated chickens. J Virol Methods. 2010;165:108-111. doi: 10.1016/j.jviromet.2009.12.008

6. Rey ME, D'Andrea E, Calvert J, Paximadis M, Boccardo G. Evidence for a phytoreovirus associated with tobacco exhibiting leaf curl symptoms in South Africa. Phytopathol. 1999;89:303-307. doi: 10.1094/PHYTO.1999.89.4.303.

7. Chu W, Qi Z, Jia-dong Z, Jian-shan L, Li-xin Z, Xi-minY, Meng-hou $\mathrm{G}$, Xue-pengC, Guo-zhong Z. Sequence and phylogenetic analysis of chicken reoviruses in China. J Int Agri. 2016;15(8):1846-1855. doi: 10.1016/S2095-3119(15)61200-X.

8. Bruhn S, Bruckner L, Ottiger HP. Application of RT-PCR for the detection of avian reovirus contamination in avian viral vaccines. $\mathrm{J}$ Virol Meth. 2005;123:179-186. DOI: 10.1016/j.jviromet.2004.09.019

9. Jones RC. Reovirus infections. In: Swayne DE, Glisson JR, McDougald LR, editors. Diseases of poultry. USA: CRC Press; 2013. 352-361 p.

10. Pu J, Liu X, Guo Y, Cao Y, Zhao J, Zhang G. Seroprevalence of avian reovirus in egg-laying chicken flocks in China. Avi Dis. 2008;52(4):675-679. DOI:10.1637/8300-040108-Reg.1

11. Huang L, Xie Z, Xie L, Deng X, Xie H, Luo S, Huang J, Zeng T, Feng J. A duplex real-time PCR assay for the detection and quantification of avian reovirus and Mycoplasma synoviae. Virol J. 2015;12:22:2-9. doi: 10.1186/s12985-015-0255-y.

12. Guan MK, Cheng LH, Ke LY, Ji WT, Chulu LC, Liao MH, Chang TJ, Liu HJ. Development of a quantitative light cycler real-time RT-PCR for detection of avian reovirus. J Virol Meth. 2006;133:6-13. DOI:10.1016/j.jviromet.2005.09.011

13. Xie Z, Peng Y, Luo S, Wang Y, Liu J, Pang Y. Development of a reverse transcription loop-mediated isothermal amplification assay for visual detection of avian reovirus. Avi Pathol. 2012;41:311-6. doi: 10.1080/03079457.2012.686104. 